\title{
Person of the Issue: Anna Freud (1895-1982)
}

\author{
Ankit Patel $^{1}$
}

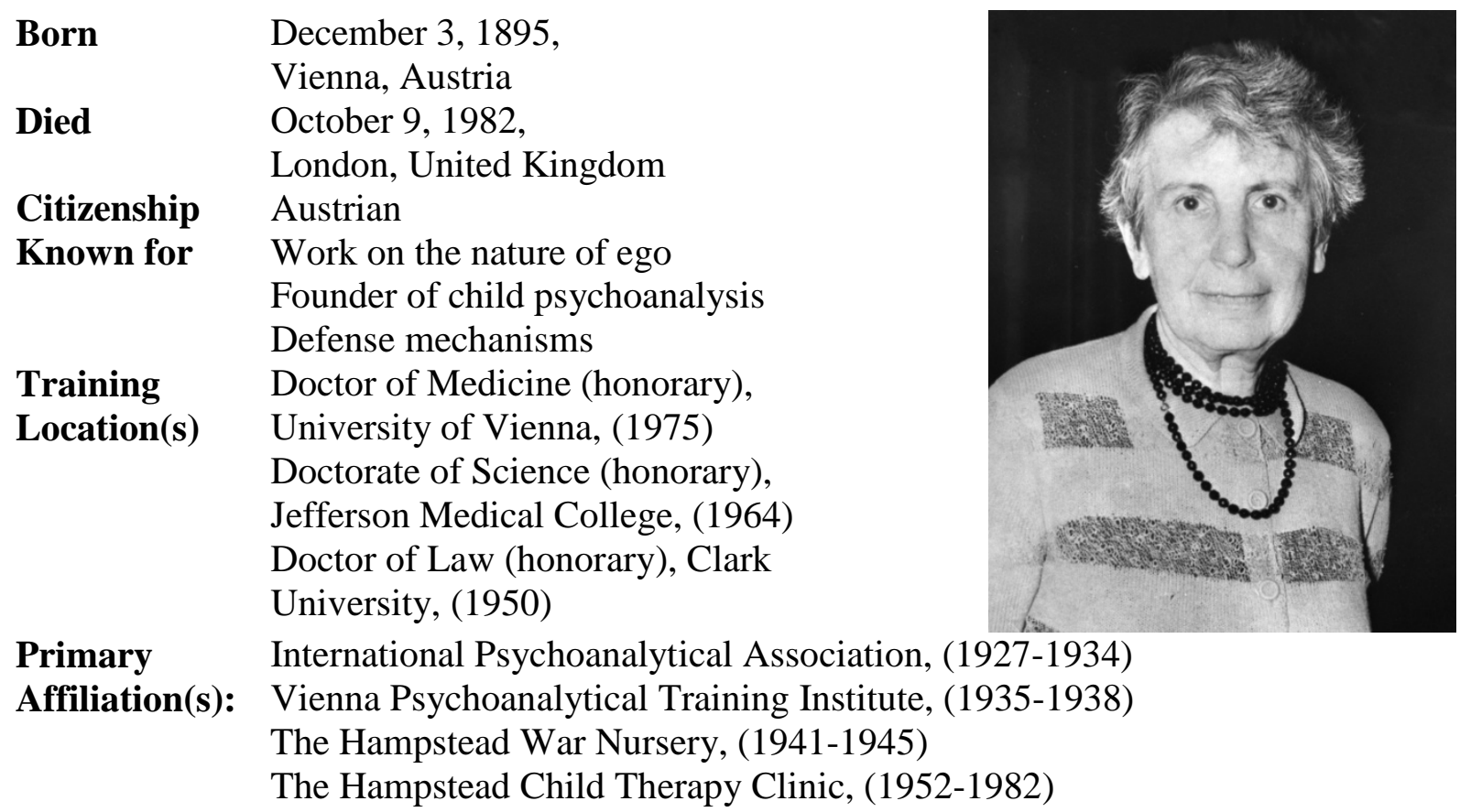

The name Freud is most often associated with Sigmund, the Austrian doctor who founded the school of thought known as psychoanalysis. But his youngest daughter, Anna, was also an influential psychologist who had a major impact on psychoanalysis, psychotherapy, and child psychology. Anna Freud did more than live in her father's rather long shadow. Instead, she becomes one of the world's foremost psychoanalysts. She is recognized as the founder of child psychoanalysis, despite the fact that her father often suggested that children could not be psychoanalyzed.

Anna Freud was born December 3, 1895 in Vienna, Austria. As the daughter of Sigmund Freud, she was inescapably steeped in the psychoanalytic theories of her famous father; however, she did more than simply live in his shadow, pioneering the field of child psychoanalysis and extending the concept of defense mechanisms to develop ego psychology. After finishing her secondary education in 1912 at Cottage Lyceum in Vienna, she completed teachers' training and worked at her alma mater as a classroom teacher for five years. Of her school years she declared that she learned far more at home from her father and his guests. Indeed, she acquired knowledge of psychoanalysis from this group to which few others had access, and this grounded her lifelong contributions to the field.

\footnotetext{
${ }^{1}$ Clinical Psychology, Dept. of Psychology, Sardar Patel University, Vallabh Vidyanagar, Gujarat

(c) 2015 A Patel; licensee IJIP. This is an Open Access Research distributed under the terms of the Creative Commons Attribution License (http://creativecommons.org/licenses/by/2.0), which permits unrestricted use, distribution, and reproduction in any Medium, provided the original work is properly cited.
} 
The details of Anna Freud's personal life are consistently cryptic, but that her father was the only man in her life long-term is certain. Letters between her and Eva Rosenfeld during the Vienna years are a rare opportunity to catch a glimpse of the very private Anna. According to contributor Gunter Bittner, the letters "convey the picture of an affectionate, intensely human Anna Freud without a trace of rigidity or psychoanalytic orthodoxy. Here...is a shy young woman of deep feeling. "Indeed she said of herself, "I was always looking outside myself for strength and confidence but it comes from within. It is there all the time."

Anna Freud died on October 9, 1982 at the age of 86 at her London home. A tribute published in the New York Times following her death, noted that "Freud virtually invented the systematic study of the emotional and mental life of the child and elaborated on it in 50 years of observation, discussion and writing." She stepped out from beneath her father's very long shadow to make her own very substantial mark upon the field of psychoanalysis, but always remained loyal to his memory and determined to secure his legacy. Upon her death, the Freud family home became a museum dedicated to him.

\section{TIME LINE}

1895- Born December 3 in Vienna, the sixth and youngest child of Sigmund and Martha Freud is born. They name her Anna.

1905- Anna starts school at Salka Goldman Cottage Lyceum - she will later return here as a teacher.

1909- From the age of 14 Anna Freud's interest in psychoanalysis was clear. This paved the way for the rest of career.

1912- Finished schooling at Cottage Lyceum, Vienna

1914- During a holiday to England, WW1 breaks out, meaning Anna must flee back to Vienna as an enemy alien.

1914 Sept.- Returning to her old school, Salka Goldman Cottage Lyceum, she begins her teacher qualification.

1918- Although parent/child psychoanalysis is deemed controversial, this series of psychoanalysis was, in the end, concluded as successful.

1920- After 6 years at her old school she finally qualifies as a teacher. This experience becomes invaluable in her child psychoanalysis research.

1920- Attended the International Psychoanalytic Congress at The Hague

1922- Anna reads a formal paper to the Viennese Psycholanalytic Society in order to become an accredited member.

1922 Oct.- Anna attends the International Psychoanalytic Congress of Psychoanalysis in Berlin, founded by her father.

1922- Presented paper Beating Fantasies and Daydreams to Vienna Psychoanalytic Society and became a member

1922-1935 Introduction to Psychoanalysis

1925- Taught seminar at Vienna Psychoanalytic Institute on technique of Child Analysis 
1927- Introduction to the Technique of Child Analysis

1927-1934- General secretary of the International Psychoanalytic Association

1935- Director of Vienna Psychoanalytic Training Institute

1936- The Ego and the Mechanisms of Defense

1937- 'The Ego and the Mechanisms of Defence', the first of Anna's books, is published in English. To this day it remains a very important work.

1938- As the Nazis enter Vienna, the Jewish Freud family leave Austria and flee to England.

1939- Anna's father Sigmund Freud dies from jaw cancer less than a year after their move to England.

1939- With the outbreak of World War Two Anna sets up residential war nurseries in Hampstead for homeless children of war.

1939-1945-Infants without Families

1941-1945- Harsh divisions between Anna and her colleague Melanie Klein, documented in a series of Controversial Discussions, end when the British Psycho-Analytic Society split into three training divisions, however the Society remained whole

1945-1956- Indications for Child Analysis and other papers

1947- Establishment of Hampstead Child Therapy Courses and children's clinic

1950- Honorary doctorate from Clark University

1950 to death- traveled back and forth to US to give lectures

1951- Anna's mother, Martha Freud, dies.

1956-1965 Research at the Hampstead Child Therapy Clinic

1965- Anna's seventh title is published, one of her most important books which continues to make contributions in the fields of education and paediatrics.

1965- Normality and Pathology in Childhood

1967- Problems of Psychoanalytic Training, Diagnosis and the Technique of Therapy

1967- Received C.B.E. from Queen Elizabeth II

1968- Publication of collected works

1970- Psychoanalytic Theory of Normal Development

1972- Received honorary medical doctorate from Vienna University

1973- Received honorary president of International Psychoanalytic Association 1975- Anna receives her MD from the University of Vienna.

1981- Anna is awarded with a PhD from Goethe Institute in Frankfurt.

1982- Died October 9th

1983- Hampstead Clinic becomes Anna Freud Center as tribute to her memory

1986- Home of 40 years changed into the Freud Museum 


\section{AWARDS \& ACHIEVEMENTS}

- In 1965, she received the Dolly Madison Award.

- In 1967, she was named a Commander of the British Empire by Queen Elizabeth II.

- In 1975, she was awarded an MD degree from the University of Vienna. The same year, she also received the Grand Decoration of Honor in Gold.

\section{MAJOR WORKS}

- She created the field of child psychoanalysis and her work contributed greatly to the understanding of child psychology. She noted that children's symptoms differed from those of adults and were often related to developmental stages.

- One of her most significant published works is 'The Ego and the Mechanisms of Defense' in which she outlined and expanded upon her father's theory of psychological defense mechanisms.

\section{QUOTES}

“Creative minds have always been known to survive any kind of bad training."

"I was always looking outside myself for strength and confidence but it comes from within. It is there all the time."

"Create around one at least a small circle where matters are arranged as one wants them to be."

\section{REFERENCES \\ About Education, "Anna Freud Biography (1895-1982)" Reserved from; http://psychology.about.com/od/profilesofmajorthinkers/p/bio_annafreud.htm [25 Oct. 2015, 11.18 PM] \\ FREUD MUSEUM LONDON, "TIMELINE"; $\quad$ Reserved from; http://www.freud.org.uk/education/timeline/ [25 Oct. 2015, 11.37 PM] \\ Psychology's $\quad$ Feminist $\quad$ Voices, "anna-freud" Reserved http://www.feministvoices.com/anna-freud/ [25 Oct. 2015, 11.30 PM]}

Photo Credit by: Wikipedia.Org 